\title{
Tomato production as a function of aeration levels after subsurface drip irrigation ${ }^{1}$
}

\author{
Jean Marcelo Rodrigues do Nascimento ${ }^{2}$, Roberto Rezende ${ }^{2}$, \\ Cássio de Castro Seron ${ }^{2}$, Álvaro Henrique Cândido de Souza ${ }^{2}$, André Felipe Barion Alves Andrean ${ }^{2}$
}

\section{ABSTRACT}

After rain or irrigation, the soil pores may present a low oxygen content (hypoxia). Soil aeration after irrigation has been used to overcome hypoxia-based problems. This study aimed to investigate the effect of four aeration levels $(0,0.5,1.0$ and 1.5 times the standard volume) applied after irrigation, using a subsurface drip system, at two soil depths $(0.15 \mathrm{~m}$ and $0.30 \mathrm{~m})$. A randomized block design was used, in a $4 \times 2$ factorial scheme, with six replications. The yield characteristics assessed were: total fruit mass per plant, average fruit mass and number of fruits per plant. The growth characteristics were root and stem dry mass. The water-use efficiency was also calculated. The results indicated that the highest aeration level, at a depth of $0.30 \mathrm{~m}$, increased the yield by $41.2 \%$, when compared with plants that received only irrigation, at the same depth. The water-use efficiency was influenced by the soil aeration after irrigation only at the depth of $0.30 \mathrm{~m}$.

KEYWORDS: Solanum lycopersicum, air injection into the soil, soil hypoxia.

\section{INTRODUCTION}

Tomato (Lycopersicon esculentum L.) is the second most important culinary vegetable in the world, behind potato, but ranks the first place, in terms of fresh vegetable consumption (Santos 2009). The tomato cultivation encompassed 4.7 million hectares in 2017, resulting in a yield of 161 million metric tons, led by China (59 million), with Brazil ranking the ninth position (3.5 million) (FAO 2017).

Tomatoes destined for fresh consumption have been produced primarily in greenhouses, using subsurface drip microirrigation to save water and fewer fungicides, if compared to the sprinkler

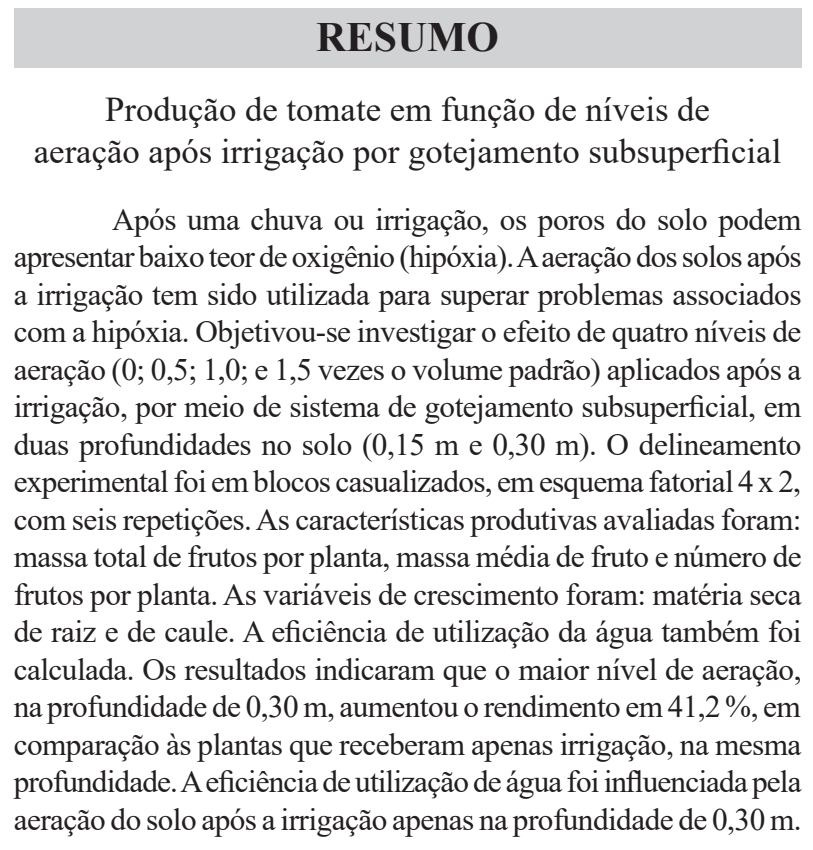

PALAVRAS-CHAVE: Solanum lycopersicum, insuflação de ar no solo, hipóxia do solo.

irrigation. However, this method may also promote the occurrence of soil-borne diseases. Thus, an alternative is the subsurface drip system, which also reduces the water loss by evaporation, minimizes the incidence of diseases and enables a direct nutrient application to the root zone (Ayars 2015).

Most agricultural crops require a continuous and adequate oxygen $\left(\mathrm{O}_{2}\right)$ supply in the soil to enable respiration, growth, development and normal metabolic functions ( $\mathrm{Li}$ et al. 2016). Soil aeration after irrigation has been used to overcome problems associated with hypoxia (low oxygen content) in the root zone of irrigated crops such as cucumber and maize (Niu et al. 2013). Li et al. 
(2016) found quantitative and qualitative benefits to tomato crops by aerating silty soil at depths of $0.15 \mathrm{~m}$ and $0.40 \mathrm{~m}$.

This study aimed to analyze the effect of air injection and application depths on the yield characteristics and growth of tomatoes.

\section{MATERIAL AND METHODS}

The experiment was performed from April to August 2018, in a greenhouse of the Universidade Estadual de Maringá $\left(23^{\circ} 25^{\prime} \mathrm{S}, 51^{\circ} 57^{\prime} \mathrm{W}\right.$ and altitude of $542 \mathrm{~m}$ ), in Maringá, Paraná state, Brazil. The greenhouse was composed of an arch-shaped roof covered with $150 \mu \mathrm{m}$-thick polyethylene film ( $25 \mathrm{~m}$ long, $7 \mathrm{~m}$ wide and $3.0 \mathrm{~m}$ high), with an anti-insect net on the sides.

The climate in the region is $\mathrm{Cfa}$ (humid mesothermal) (Alvares et al. 2013), according to the Köppen classification, which is characterized by abundant rainfall in the summer and dry winters, with average temperature of $21.8{ }^{\circ} \mathrm{C}$ and relative humidity of $66 \%$.

The soil in the experimental area was classified as a Dystroferric Red Nitosol (Santos et al. 2018), whose chemical properties are summarized in Table 1. The particle size distribution of the soil was $175 \mathrm{~g} \mathrm{~kg}^{-1}$ of sand, $90 \mathrm{~g} \mathrm{~kg}^{-1}$ of silt and $735 \mathrm{~g} \mathrm{~kg}^{-1}$ of clay, at a soil density of $1.37 \mathrm{Mg} \mathrm{m}^{-3}$. The soil moisture/field capacity level is $0.47 \mathrm{~m}^{3} \mathrm{~m}^{-3}$, at a potential of $60 \mathrm{hPa}$, and the permanent wilting time $0.33 \mathrm{~m}^{3} \mathrm{~m}^{-3}$, at a potential of 15,000 hPa (Blainski 2007).

The irrigation system consisted of a $0.5 \mathrm{HP}$ water pump, $500 \mathrm{~L}$ reservoir, gate valve, hydrometer, quick connector and disc filter. The lateral lines were made of $16 \mathrm{~mm}$ polyethylene with fifteen $1.8 \mathrm{~L} \mathrm{~h}^{-1}$ self-compensating online drippers spaced $0.2 \mathrm{~m}$ apart, in order to provide a continuous irrigation. The drip lines were buried at a depth of $0.15 \mathrm{~m}$ or $0.30 \mathrm{~m}$, in line with the experimental design adopted. Spacing between the lateral lines was the same as between the crop rows $(1.15 \mathrm{~m})$.
The crop water replacement was led through subsurface drip irrigation on Mondays, Wednesdays and Fridays, based on the reference crop evapotranspiration (ETo). The ETo was estimated according to the modified Penman-Monteith equation for protected environment (McNaughton \& Jarvis 1983). An automated Campbell Scientific weather station was used to collect the climate data and a CR1000 Datalogger model for storage.

The crop coefficient $(\mathrm{Kc})$ values used were 0.4- 0.5 (from the emergence to $10 \%$ of soil coverage, by day 20 ), $0.70-0.80$ (from $10 \%$ to $80 \%$ of soil coverage, by day 50 ), $1.05-1.25$ (from $80 \%$ to $100 \%$ of soil coverage, by day 70), 0.80-0.95 (physiological maturity, by day 92) and 0.60-0.65 (harvest, by day 121). The location coefficient $\left(\mathrm{K}_{\mathrm{Loc}}\right)$ considered on the irrigation management was steady: $\mathrm{K}_{\mathrm{Loc}}=0.5$.

The experiment involved planting Seminis SV2333TJ hybrid tomato seeds, which exhibit indeterminate growth, oblong fruit, average weight of $130 \mathrm{~g}$ and bright red color. Seeds were planted in 128-cell plastic trays filled with commercial substrate, at one seed per cell, and kept in a greenhouse for seedling development. Transplanting took place when the seedlings contained four or five definitive leaves, what occurred at 35 days after planting (DAP).

The greenhouse was divided into 48 plots, $3.0 \mathrm{~m}$ long and $0.5 \mathrm{~m}$ wide, totaling an area of $1.5 \mathrm{~m}^{2}$ in each plot. The plants were allocated to the central row of the plot, $0.5 \mathrm{~m}$ apart.

A randomized complete block design, with six replications, was arranged in a $2 \times 4$ factorial scheme. The first factor consisted of two depths in the subsurface drip system: $0.15 \mathrm{~m}$ (D15) and $0.30 \mathrm{~m}$ (D30). The second factor involved four aeration volumes: no aeration (V0); 0.5 times the standard volume (V1); 1.0 times the standard volume (V2); and 1.5 times the standard volume (V3). The standard aeration volume (SAV) was also used by Li et al. (2016) to aerate silty soil for a tomato crop, being calculated according to the following equation $\left(\right.$ expressed in $\left.\mathrm{m}^{3}\right): \mathrm{SAV}=(\mathrm{s} . \mathrm{L} . \alpha) / 100$, where: $\mathrm{s}$ is

Table 1. Chemical properties of the soil in the experimental area.

\begin{tabular}{|c|c|c|c|c|c|c|c|c|c|c|c|c|c|}
\hline \multirow{3}{*}{$\begin{array}{l}\text { Depth } \\
\text { (m) }\end{array}$} & \multirow{3}{*}{$\begin{array}{c}\mathrm{pH} \\
\left(\mathrm{H}_{2} \mathrm{O}\right)\end{array}$} & \multicolumn{6}{|c|}{ Macronutrients } & \multicolumn{6}{|c|}{ Micronutrients } \\
\hline & & \multirow{2}{*}{$\frac{\mathrm{P}}{\mathrm{mg} \mathrm{dm^{-3 }}}$} & $\mathrm{K}^{+}$ & $\mathrm{Ca}^{+2}$ & $\mathrm{Mg}^{+2}$ & $\mathrm{Al}^{+3}$ & $\mathrm{H}+\mathrm{AL}$ & $\mathrm{Cu}$ & $\mathrm{Zn}$ & $\mathrm{Fe}$ & $\mathrm{Mn}$ & $\mathrm{Na}^{+}$ & $\mathrm{B}$ \\
\hline & & & \multicolumn{5}{|c|}{$\mathrm{cmol}_{\mathrm{c}} \mathrm{dm}^{-3}$} & \multicolumn{6}{|c|}{$\mathrm{mg} \mathrm{dm}^{-3}$} \\
\hline $0.00-0.20$ & 6.8 & 128.3 & 0.5 & 8.6 & 1.9 & 0 & 2.7 & 18.5 & 30.9 & 164.8 & 103.2 & 33.4 & 0.3 \\
\hline $0.20-0.40$ & 6.8 & 72.8 & 0.3 & 7.3 & 1.7 & 0 & 3.4 & 25.0 & 19.7 & 133.1 & 96.0 & 32.5 & 0.3 \\
\hline
\end{tabular}


the cross-sectional area of the possibly aerated plot $\left(\mathrm{m}^{2}\right)$, L the plot length $(\mathrm{m})$ and $\alpha$ the soil porosity $(\%)$.

The cross-sectional area of the plot was the product of the plot width $(0.5 \mathrm{~m})$ and the theoretical height of the dripper $(0.15 \mathrm{~m})$. Thus, the standard aeration volume per plot was $\mathrm{SAV}=[(0.5 \mathrm{~m} \mathrm{x}$ $0.15 \mathrm{~m}) \times 3 \mathrm{~m} \times 57] / 100=0.1285 \mathrm{~m}^{3}$.

Air applications (aeration) were always carried out after the crop irrigation, three times a week. Following irrigation, the lateral lines were closed and the end of the main line opened to remove the water from the pipes. The aeration of the system began at the end of the water evacuation. To that end, an air compressor was connected to the main irrigation line by a quick $\mathrm{T}$ connector. The air flow at the inlet of the irrigation system was measured by a hydrometer, which indicated $2.268 \mathrm{~L} \mathrm{~h}^{-1}$ (36 plots), equivalent to $63 \mathrm{~L} \mathrm{~h}^{-1} \operatorname{plot}^{-1}\left(0.063 \mathrm{~m}^{3} \mathrm{~h}^{-1}\right.$ plot $\left.^{-1}\right)$.

The air injection time for the standard aeration volume $(\mathrm{t}$ ) was calculated by $\mathrm{t}=\mathrm{SAV} / \mathrm{Qc}$, where $\mathrm{Qc}$ is the air flow per plot $\left(\mathrm{m}^{3} \mathrm{~h}^{-1}\right)$.

Based on the standard aeration volume and air flow per plot, the standard aeration time (2h02min) was calculated. The aeration levels were applied considering a fraction of the standard aeration time, being $1 \mathrm{~h} 01 \mathrm{~min}$ and $3 \mathrm{~h} 03 \mathrm{~min}$ for $\mathrm{V} 1$ and V3, respectively. The treatments were applied at 21 days after transplanting, the time considered for seedling establishment.

Harvest occurred between 87 and 121 days after transplanting, removing only the fruits that were completely red every day. The fruits were taken to the laboratory and weighed on a bench scale accurate to $0.01 \mathrm{~g}$. These data were used to calculate the yield, number of fruits per plant and average fruit mass.

After the harvest, two plants were collected from the center of each plot, and taken to the laboratory to separate the plant parts (roots and stem). These were dried in an air circulation oven at $60^{\circ} \mathrm{C}$, until reaching a constant mass $(72 \mathrm{~h})$, and used to determine the root and stem dry mass.

The water-use efficiency (WUE) $\left(\mathrm{kg} \mathrm{kg}^{-1}\right)$ was calculated as the ratio between yield and the amount of water applied per plant: WUE $=\mathrm{Y} / \mathrm{I}$, where: $\mathrm{Y}$ is the yield $\left(\mathrm{kg} \mathrm{plant}^{-1}\right)$ and I the applied water depth $\left(\operatorname{kg~plant}^{-1}\right)$.

The data were submitted to analysis of variance and, if the treatment effects were significant $(p<0.05)$, their means were compared using the Tukey test at $5 \%$ of probability. The Sisvar software (Ferreira 2014) was used for the analyses. Polynomial models were adjusted for variables with significant treatment effects, considering the significance $(\mathrm{p}<$ 0.05 ) of the regression coefficients.

\section{RESULTS AND DISCUSSION}

The results of the present study showed significant differences $(\mathrm{p}<0.01)$ between the treatments for the variables yield and water-use efficiency (Table 2). There were no significant differences between the blocks $(p>0.05)$ and no variation in the plant location. It is important to underscore that the interaction between the factors occurred just for yield.

Based on the analysis of variance, there was interaction between the aeration levels and depths for yield, what allowed to fit the regression equation to represent the variation of yield as a function of aeration levels at $30 \mathrm{~cm}$ (Figure 1). However, it could not fit at $15 \mathrm{~cm}$, because there were no significant differences.

The so-called chimney effect occurs when pipes buried at shallow depths stimulate more superficial

Table 2. Summary of the analyses of variance for the tomato crop submitted to aeration volumes and application depths.

\begin{tabular}{lccccccc}
\hline \multicolumn{1}{c}{$\begin{array}{c}\text { Source of } \\
\text { variation }\end{array}$} & \multirow{2}{*}{ DF } & \multicolumn{7}{c}{ Y } & NFP & MFM & Dean square & DSM & DRM & WUE \\
\hline Block & 5 & $0.0865^{\text {ns }}$ & $11.800^{\text {ns }}$ & $620.295^{\text {ns }}$ & $374.28^{\text {ns }}$ & $2.071^{\text {ns }}$ & $0.000043^{\text {ns }}$ \\
Depth (D) & 1 & $0.5740^{* *}$ & $24.083^{\text {ns }}$ & $79.310^{\text {ns }}$ & $459.54^{\text {ns }}$ & $4.200^{\text {ns }}$ & $0.000133^{* *}$ \\
Aeration (A) & 3 & $0.3822^{* *}$ & $8.472^{\text {ns }}$ & $1,525.66^{\text {ns }}$ & $422.45^{\text {ns }}$ & $0.822^{\text {ns }}$ & $0.000114^{* *}$ \\
D x A & 3 & $0.5677^{* *}$ & $6.020^{\text {ns }}$ & $1,271.42^{\text {ns }}$ & $870.30^{\text {ns }}$ & $14.280^{\text {ns }}$ & $0.000028^{\text {ns }}$ \\
Error & 35 & 0.0660 & 17.960 & 665.96 & 647.57 & 6.204 & 0.000018 \\
\hline CV $(\%)$ & - & 9.74 & 19.83 & 20.27 & 22.11 & 26.65 & 17.07 \\
\hline Mean & - & 2.64 & 21.37 & 127.30 & 115.11 & 9.35 & 0.0245 \\
\hline
\end{tabular}




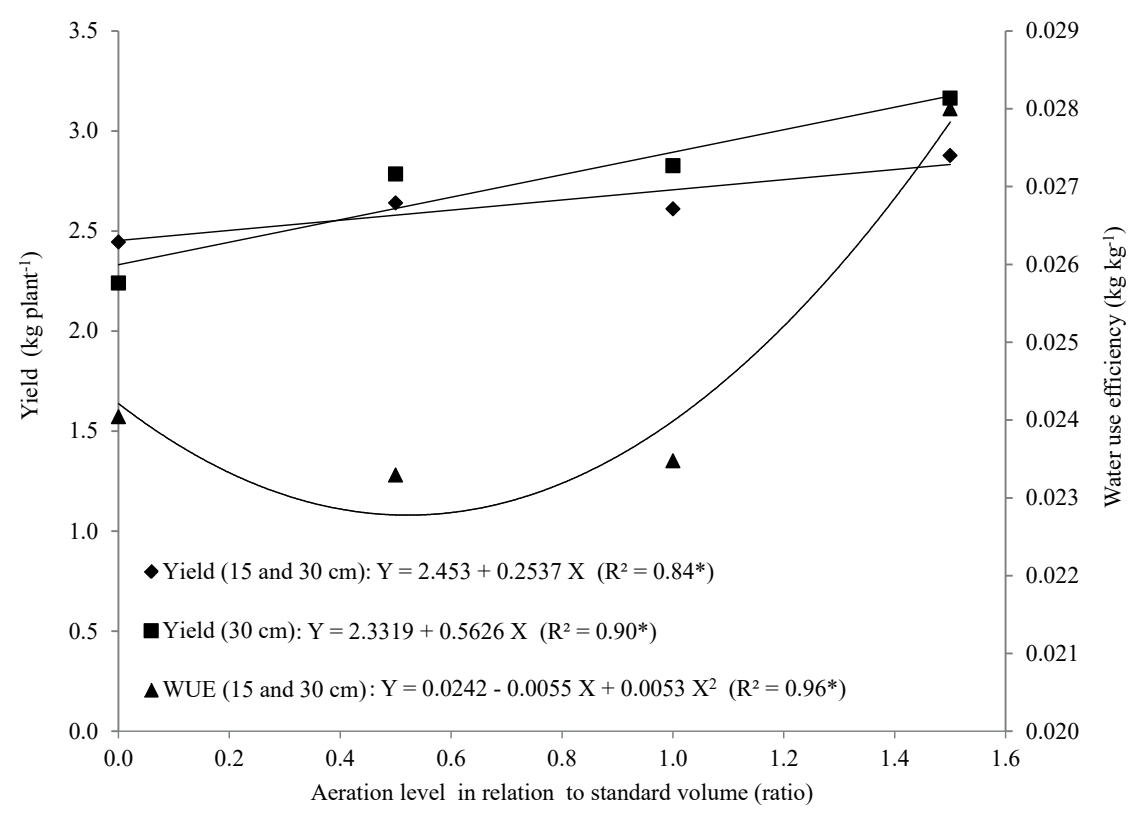

Figure 1. Yield and water-use efficiency (WUE) of the tomato crop, as a function of the aeration levels in two depths (15 $\mathrm{cm}$ and $30 \mathrm{~cm}$ ).

rooting. Thus, the interlinking of pores from beneath the soil to the surface forms a pathway that provides a satisfactory air supply to the roots. This was likely why there were no significant differences for the variable yield between the treatments, as a function of soil aeration at a depth of $0.15 \mathrm{~m}$ (Li et al. 2016).

The yield increased from $2.33 \mathrm{~kg}$ plant $^{-1}$ to $3.17 \mathrm{~kg}$ plant $^{-1}$, respectively for $\mathrm{V} 0$ and $\mathrm{V} 3$, at a depth of $0.30 \mathrm{~m}$ (Table 2), what corresponds to an increase of $36.3 \%$ for yield. With each unit of standard air volume applied, the yield rose $562.6 \mathrm{~g} \mathrm{plant}^{-1}$ at a depth of $0.30 \mathrm{~m}$ and $253.7 \mathrm{~g} \mathrm{plant}^{-1}$ at $0.15 \mathrm{~m}$ and $0.30 \mathrm{~m}$. The lack of oxygen results in a number of substances, such as the plant hormones abscisic acid (ABA) and ethylene, in addition to ethanol (KatoNoguchi 2000). The ABA accumulation, in turn, may lead to less stomatal opening, reduced stomatal density and a decline in the net photosynthetic rate, due to the lower $\mathrm{CO}_{2}$ influx into the plant (Chater et al. 2015).

Significant differences for maize yield were observed by Abuarab et al. (2013), when soil (sandyclay-loam) aeration was used at a depth of $0.20 \mathrm{~m}$, if compared to the treatment without aeration. $\mathrm{Li}$ et al. (2016) tested different aeration volumes in a sandy soil (silt-clay-loam) and observed that the tomato crop was influenced at the depths of $0.15 \mathrm{~m}$ and $0.30 \mathrm{~m}$. Niu et al. (2013) found no increase in cucumber yield when 0.50 of standard volume was applied, but it rose for 0.75 and 1.00 times the standard volume. These authors considered half of the standard volume adopted in the present study.

The best water-use efficiency $\left(0.027 \mathrm{~kg} \mathrm{~kg}^{-1}\right)$ occurred at the highest aeration volume. Li et al. (2016) found that different aeration volumes in a tomato crop, at a depth of $0.40 \mathrm{~m}$, increased the wateruse efficiency from $0.013 \mathrm{~kg} \mathrm{~kg}^{-1}$ to $0.027 \mathrm{~kg} \mathrm{~kg}^{-1}$. Bhattarai et al. (2006) applied oxygen via irrigation water (Venturi tube), what increased the water-use efficiency of the tomato crop from $0.0041 \mathrm{~kg} \mathrm{~kg}^{-1}$ to $0.0047 \mathrm{~kg} \mathrm{~kg}^{-1}$ (based on the fruit dry mass).

A greater water-use efficiency in maize plants aerated by forced air injection into the soil was observed by Abuarab et al. (2013). Niu et al. (2013) obtained the highest water-use efficiency for 0.75 and 1.0 times the standard volume, with no significant differences between the treatments without aeration and that with 0.50 times the standard volume, at a depth of $0.15 \mathrm{~m}$. These authors also found that the cucumber plant height increased with the soil aeration technique.

This result agrees with that reported by Abuarab et al. (2013), who also found an increase in the height and diameter of maize plants with soil aeration. However, the stem growth assessed in the present study exhibited no significant differences. Bhattarai et al. (2006) reported no statistical differences for stem and root dry mass, corroborating the findings obtained here. 
The results showed that applying irrigation at a depth of $0.30 \mathrm{~m}$ along with $150 \%$ of standard aeration produced a higher yield and greater water-use efficiency. Thus, aeration may mitigate the temporal hypoxia of tomatoes planted in a Dystroferric Red Nitosol.

The regression model could not be fit to yield and water-use efficiency, as a function of aeration, at a depth of $0.15 \mathrm{~m}$. When the drip tube is buried at a shallower depth, such as $0.15 \mathrm{~m}$, the aeration volume may cause a decline in tomato yield (Li et al. 2016). It is suggested that tomato roots are abundant at this depth and that aeration may reduce the root-soil contact, having a negative effect on their primary functions.

Since most the roots are normally above $0.30 \mathrm{~m}$, the air flow is not applied directly to them at this depth. This makes the aeration effect more beneficial to the plant, decreasing the stress due to lack of oxygen in the root zone and maintaining the root-soil contact.

\section{CONCLUSIONS}

1. Soil aeration after irrigation influences the yield and water-use efficiency in tomato plants cultivated on a clayey soil;

2. The highest yield and water-use efficiency take place under irrigation and aeration of 1.5 times the standard volume at $0.30 \mathrm{~m}$.

\section{ACKNOWLEDGMENTS}

The authors thank the Coordenação de Aperfeiçoamento de Pessoal de Nível Superior (Capes) and Conselho Nacional de Desenvolvimento Científico e Tecnológico ( $\mathrm{CNPq})$, for the research grants provided during this study.

\section{REFERENCES}

ABUARAB, M.; MOSTAFA, E.; IBRAHIM, M. Effect of air injection under subsurface drip irrigation on yield and water use efficiency of corn in a sandy clay loam soil. Journal of Advanced Research, v. 4, n. 6, p. 493499, 2013.

ALVARES, C. A.; STAPE, J. L.; SENTELHAS, P. C.; GONÇALVES, J. L. M.; SPAROVEK, G. Köppen's climate classification map for Brazil. Meteorologische Zeits, v. 22, n. 6, p. 711-728, 2013.
AYARS, J. E.; FULTON, A.; TAYLOR, B. Subsurface drip irrigation in California: here to stay? Agricultural Water Management, v. 157, n. C, p. 39-47, 2015.

BHATTARAI, S. P.; PENDERGAST, L.; MIDMORE, D. J. Root aeration improves yield and water use efficiency of tomato in heavy clay and saline soils. Scientia Horticulturae, v. 108, n. 3, p. 278-288, 2006.

BLAINSKI, E. Utilização do intervalo hídrico ótimo do solo para manejo de área irrigada. 2007. Dissertação (Mestrado em Agronomia) - Universidade Estadual de Maringá, Maringá, 2007.

CHATER, C.; PENG, K.; MOVAHEDI, M.; DUNN, J. A.; WALKER, H. J.; LIANG, Y. K.; MCLACHLAN, D. H.; CASSON, S.; ISNER, J. C.; WILSON, I.; NEILL, S. J.; HEDRICH, R.; GRAY, J. E.; HETHERINGTON, A. $\mathrm{M}$. Elevated $\mathrm{CO}_{2}$-induced responses in stomata require ABA and ABA signaling. Current Biology, v. 25, n. 20, p. 2709-2716, 2015.

FERREIRA, D. F. Sisvar: a guide for its bootstrap procedures in multiple comparisons. Revista Ciência e Agrotecnologia, v. 38, n. 2, p. 109-112, 2014.

FOOD AND AGRICULTURE ORGANIZATION OF THE UNITED NATIONS (FAO). Faostat. 2017. Available at: http://www.fao.org/faostat/en/\#data/QC. Access on: 27 Feb. 2019.

KATO-NOGUCHI, H. Induction of alcohol dehydrogenase by plant hormones in alfalfa seedling. Plant Growth Regulation, v. 30, n. 1, p. 1-3, 2000.

LI, Y.; WENQUAN, N.; MILES, D.; JINGWEI, W.; XIAOYANG, Z. Yields and nutritional of greenhouse tomato in response to different soil aeration volume at two depths of subsurface drip irrigation. Scientific Reports, v. 6, e39307, 2016.

MCNAUGHTON, K. G.; JARVIS, P. G. Predicting effects of vegetation changes on transpiration and evaporation. In: KOZLOWSKI, T. T. (ed.). Water deficits and plant growth. New York: Academic Press, 1983. p. 1-47.

NIU, W. Q.; FAN, W. T.; PERSAUD, N.; ZHOU, X. B. $O$. Effect of post-irrigation aeration on growth and quality of greenhouse cucumber. Pedosphere, v. 23, n. 6, p. 790798, 2013.

SANTOS, F. F. B. Obtenção e seleção de híbridos de tomate visando a resistência ao tomato yellow vein streak virus. 2009. Dissertação (Mestrado em Agricultura Tropical e Subtropical) - Instituto Agronômico, Campinas, 2009.

SANTOS, H. G. dos; JACOMINE, P. K. T.; ANJOS, L. H. C. dos; OLIVEIRA, V. A. de; LUMBRERAS, J. F.; COELHO, M. R.; ALMEIDA, J. A. de; ARAUJO FILHO, J. C. de; OLIVEIRA, J. B. de; CUNHA, T. J. F. Sistema brasileiro de classificação de solos. Rio de Janeiro: Embrapa, 2018. 